\title{
Reform of International Organizations in an Era of Chinese and US leadership
}

\author{
Yuran Wang ${ }^{1}$, Zhengjun $\mathrm{Xu}^{2 *}$, Dicheng $\mathrm{Zou}^{3}$ \\ ${ }^{1}$ Archbishop Williams High School, Braintree, Massachusetts 02184, United States \\ ${ }^{2}$ School of Law, Shanghai University of Political Science and Law, Shanghai 201701, China \\ ${ }^{3}$ College of Letters and Science, University of California, Santa Barbara, Goleta, California 93117, United States \\ *Corresponding author. Email: hayer520@icloud.com
}

\begin{abstract}
International institutions work hard to achieve Sustainable Development Goals (SDGs) by implementing multilateral cooperating systems. Over the past decade of Chinese and United States leadership, however, organizations like UNSC, UNHRC and the WTO faced many challenges. This paper will analyse the structures of these organizations and present solutions to the problem that plagued them. The possible reforms for these three institutions, respectively, are to repair the relationship between states through future collaboration, equalize the representation power of each state by making the operation transparent, and protect the common principality with an independent enforcement body. In conclusion, we should reform these institutions as well as protect them from selfish exploitation from nations.
\end{abstract}

Keywords: International organizations; Reform of international organizations; Sino-US relations; United Nations Security Council; United Nations Human Rights Council; World Trade Organization

\section{INTRODUCTION}

For the purpose of maintaining global peace and security, developing friendly relations among nations, and promoting social progress, the United Nations and some other international organizations were founded after WWII.[1] As two of the biggest superpowers in the present world, however, China and the U.S. have been competing fiercely to dominate the world. In 2018, a deliberate one-year-long trade war was launched between China and the U.S. due to the long-accumulated tariff conflicts amplified by their lust for supremacy. Under this pressing and grim situation fraught with uncertainty, many international organizations failed to function properly.

This paper analyzes the malfunction of certain international organizations and agencies under the UN administration. To this end, we will discuss the roles of UNHRC, UNSC and WTO in the era of Chinese and American leadership. Later, we will discuss the existing problems within each organization and the repercussions of the inefficiency of their committees. Finally, we will provide potential reforms for these issues. We will pay special attention to the relationship between China and the U.S., and the likely outcomes of the international organizations' regeneration under a different administration.

\section{THE INEFFICIENCY OF INTERNATIONAL ORGANIZATIONS}

After the end of the Second World War, with the establishment of the United Nations, a large number of international organizations emerged, which play a significant role in international relations in their own right.[2] Different international organizations specialize in and work to organize cooperation between countries to solve problems in their respective fields, such as collective security, economy, science, and society. Although international organizations, as subjects, play an important role in international affairs, there are also universal problems in terms of efficiency. It is clear that many imperative international issues that fall within the mandate of international organizations have not been effectively addressed, such as the Khmer Rouge regime of the 1970s, the Rwandan genocide of 1994, the Syrian civil war of 2011, and the Rohingya crisis of 2017. Meanwhile, similar problems exist in the debate over carbon emissions in the field of climate change, trade wars in the economic field, and the politicization of human rights.

As Sino-US relations take a prominent place on the 
world stage, international organizations are faced with an unprecedented need for reform in addressing their own inefficiencies. As the world's second-largest economy, China's leadership in the international community has implications for the liberal world order dominated by the United States for several decades. "Lead the reform of the global governance system." From such manifestos in 2017, it is clear that the Chinese government has an intense and clear ambition to reform and lead the reform of the existing world order.[3] Besides, during the Trump administration from 2017 to 2020, the United States also showed a different posture in global affairs. The announcement of the withdrawal of the United States from a series of international organizations and treaties such as the Paris Climate Agreement, the Iran nuclear deal, the Human Rights Council, and the World Health Organization and the act of starting a trade war against China and other countries during the Trump administration undoubtedly reduced its leadership ability and participation in global affairs. And when the Biden administration takes office in 2021 and announces its intention to return to the Iran nuclear agreement, the Paris Agreement, and the WHO, it is intended to undo the impact of the previous Trump administration. In brief, the new development of Sino-US relations and the attitudes of the two states towards global affairs may bring opportunities or negative influences to the reform of different international organizations. The following takes the UN Security Council, Human Rights Council, and World Trade Organization as examples for analysis.

\section{REFORM OF INTERNATIONAL ORGANIZATIONS}

\subsection{UNSC}

We may need to inspect the current UNSC's deficiencies for a better view of its reforms. Two major deficiencies are exposed in UNSC: the procedural legitimacy in collective decision-making process and the unsatisfactory ability in "maintaining global peace and security" after a flawed decision-making process. Concerning the UNSCs collective decision-making process, the veto rights of the UNSC five permanent member states, including China and the U.S, shall not be ignored. The security council's website mentioned each Member states has one vote, implying the equality among all Member states, but a single veto voted by any of the five permanent members can weighted heavier than the approval from all other members when blocking the potential solution of international affairs. Apart from the veto rights that gave the permanent five's nearly absolute executive power, the five permanent members also enjoys "larger, better-resourced staff and diplomatic corps", and their permanent membership also secured their comparative advantages on "build up an institutional memory of relationships, working methods" that other elected members or smaller countries are hard to reach.[4] In recent years we also see China's active participation UNSC meetings as a new "vetoer" after the U.S and Russia. Until now, China has executed seventeen vetoes, and eleven of them were voted in the past decade, a decade of China's striding national power and ambition on participating in global affairs that have challenged the U. S's status as a global leader.[5] In the following years, we may see China more actively participate in international events through its veto power with national power's support. However, the UNSC may find it harder to solve problems.

The U.N. security council's flawed structure and power distribution among members also lead to the inability of the U.N. security council in protecting the "global peace and security" that it claimed. We can closer investigate this failure through the U.N. Security Council's 7825th meeting. The five permanent members were divided into three divisions with varied views of a cease fire proposal in Syrian Civil War. The United States, with several countries, condemned Russia and Syria's government's oppressive means against the opposition, while the Russian Federation criticized the proposal that a temperate ceasefire could allow the fighters to replenish their force and the western intervention in the Syrian Civil War. China, instead of criticizing any single countries' position, showing reservation in supporting the draft resolution while it was "still serious differences," claiming that the current action on the draft solution may be not conducive to the diplomatic efforts by the countries concerned, nor is it helpful for improving the situation in Syria."[6] In this example, we may find the difficulty of creating a resolution draft that satisfied the profit of all major powers. The major powers have different profit in various events, so they intended to view events from diverse or sometimes opposing directions, while doubting other countries motives behind their actions. Thus, the UNSC does meet difficulties in reaching practical solutions rather than discussing the member's stance.

So, in this new era with the power and policy variation between those major powers, how can the UNSC be reformed to fit itself for its duty? The modifications of veto rights or the permanent members will greatly affect the power distribution inside the U.N security council or even the world, but left the current veto power uncontrolled could also trap the UNSC in stagnant. A South African expert supposed an increase in both UNSC non-permanent and permanent members to make the UNSC "more inclusive and more transparent in its decision making."[7] Though the method shall increase the security councils' legitimacy, the increased number of possible vetoes may make the security council harder to pass resolutions. Another possible path is restricting the veto rights of the 
permanent fives and the restore a certain extent of equality between countries. In 2015, a group of international leaders called the Elders' Proposal also appeal for the permanent fives not to veto resolutions "without publicly clarifying an alternative course in action."[8] However, those proposals are mainly suggestions or appeals without legal responsibility or execution power, so it cannot regulate countries actions. The solutions listed above may be defined as procedural reform that focuses on switching the mechanisms in the UNSC, and it may not solve the ongoing distrust and competition between the five permanents. We might instead focus on bridging the five permanents to cope with the distrust and tension between them. Indeed, the method faced extreme difficulties, especially when considering the extensive difference between those countries' ideology, society, and economy; but common ground is needed to turn any procedural reform proposals into reality.

\subsection{UNHRC}

The United Nations promotes and protects human rights through many subordinate organs, especially the Human Rights Council (HRC). Before the establishment of the Human Rights Council, the Commission on Human Rights had been playing a relevant role in human rights affairs. The establishment of the Human Rights Council, announced at the UN General Assembly in 2006, was the first action by the UN to completely replace an existing organ.[9]

From a historical perspective, the Commission on Human Rights was accused of being excessively politicized, having double standards, and being unprofessional. Take politicization, for example, there are some undesirable phenomena in the Commission, such as repetitious statements, bloc voting, and vote-bartering.[10] The several States accused of severe violations of human rights had become the member of the Commission, such as Sudan, Cuba, Libya, and Zimbabwe. Thus the Human Rights Council requires member states to get the seat by election, eliminates permanent members by not allowing the second reelection, and allows non-governmental organizations to become observers. These reforms in the Council, as opposed to the Commission, could go some way towards avoiding politicization and "the Rest against the West" condition.[11]

Nevertheless, the history of the Council over the past 15 years shows that it still has many flaws and deficiencies. Russia's incursions in Georgia and South Ossetia, and the issue of human rights in Tibet before the 2008 Beijing Olympics, were not mentioned in the Council for the same politicization reason.[12] On the other hand, the issue of Israel and Syria has received too much attention in the Council compared with similar crises. For example, the issue of the occupied
Palestinian territories, as it relates to Israel, received too much attention in the council's early meetings, while human rights in North Korea and Congo were ignored.[13] In terms of the special session, countries related to the Arab Spring uprisings, such as Bahrain, Egypt, Tunisia, and Yemen, were not singled out for special sessions, as was the case with Syria.[14] So that the Council's work and concerns are selective, and various countries are not treated in the Council in proportion to their actual human rights records.[15]

Both China and the United States have a definite influence worldwide, but their attitudes and methods of participation in the affairs of human rights are different. Due to the authoritarian nature of the Chinese Communist government, the exact human rights situation in China is opaque. But judging from Beijing's actions towards Hong Kong in 2019 and the Joint Statement on Xinjiang by the government of Canada, the United Kingdom, and the United States on March 22, 2021, the conditions of human rights in China are not optimistic.[16] At the same time, the human rights situation in the United States has also been problematic in recent years. In 2018, the UN High Commissioner for Human Rights Zeid Ra'ad Al Hussein criticized the forced separation of children from their parents for undocumented immigration at the US-Mexico border.[17] But the United States is one of the democracies that pays the most attention to human rights affairs in the western world and also placed the issue of human rights at the top of its China policy.[18]

In global disputes over human rights and sovereignty, both China and some developing countries tend to relegate human rights to secondary status, which has led to China's distinct views on human rights from the United States and the liberal world. As an illustration, after a failed attempt by the United States to return to the Commission in 2001, China's official Xinhua News Agency said the US used "human rights ... as a tool to pursue its power politics and hegemony in the world".[19]

As the leadership of China and the United States collides and balances with each other, the United Nations human rights affairs field and the Council are bound to become a key venue for conflicts between the two countries. The Human Rights Council could address these conflicts by revising its membership criteria, such as the two-thirds majority standard proposed by the United States in 2006, which, despite its flaws, pointed the council in a clear direction for reform.[20] To summarize, politicization has not been avoided from the reform of the Commission on Human Rights to the Human Rights Council. With the increase of China's leadership and China's impact on the original liberal world order, the politicization of the Council will become more severe. As one of the most crucial human rights organs of the United Nations, this situation will 
hinder the implementation of human rights law worldwide. Moreover, under the influence of the values of authoritarian governments, the Council's urgent need to address remains politicization. Significantly, Over the past few years, the Western community has become increasingly aware that the protection of human rights is vital to global peace and development.[21] As the conflict of leadership and ideology between China and the United States is difficult to reconcile in the aspect of human rights, whether the Council can make effective reform is closely related to whether the United Nations can uphold the original intention and principles of its establishment.

\subsection{WTO}

The World Trade Organization (WTO) has been the cornerstone of the multilateral rule-based global trading system since its inception in 1995.[22] Under the purpose of making global trade more accessible and free, the WTO works mainly to settle commercial disputes between states, reach commercial compromises, and protect the trade of services.[23] Among the WTO's 164 state members, China and the U.S. are notorious rivals that recently encountered major conflicts. These rivals fought a trade war under the general council and ministerial conference of the WTO. There are three main causes for the malfunction of the WTO: internal institutional problems, systematic problems also seen in other organizations, and pressure from Sino-American adversaries.[24]

Examining the structure of the WTO, we found many ambiguous regulations and quasi-rules formed in the past 56 years as well as a lack of transparency in the decision-making inherited from its predecessor -- The General Agreement on Tariffs and Trade (GATT). From a macro-level perspective, more problems can be found in the boundaries between developed and developing countries and the crisis of legitimacy.[25,26] In Particular, the definitions for developing countries and developed countries are unclear and outdated and are hard to distinguish based on specific agreement rules among international organizations.[27,28] Subsequently, some states that have undergone a significant economic change and qualified for joining developed countries chose to remain as developing countries to receive welfare and special subsidies in trading. A recent example would be China's exceeding Japan in 2010 to become the second largest economy in the world while retaining the status of a developing country. Furthermore, governments of international institutions experienced major mistrust from the public on account of restrictions placed on domestic sovereignty.[29] Focusing on the WTO, states are expected to follow the lead of the institution and pay for the possible loss of policy space using the economic and security interest provided by it. Unfortunately, since the rules of the
WTO are not fixed, the choices made by the supreme judicial body - the Appellate Body - can easily be swayed. This can happen because of the domestic sovereignty of influential constituents such as the E.U. and the U.S., who wield abundant diplomatic and economic resources. Therefore, the very legitimacy of the WTO can be controversial because of the problems in trade liberalization, globalization, and the equal distribution of profits for different continental states.[30] Lastly, the apprehension caused by the hostility between the Chinese and U.S. governments broke the delicate balance maintained before Trump's administration. Due to the detrimental and unfair bilateral trade history with China, the U.S. blocked the operation of the Appellate Body under the Dispute Settlement Body (DSB) of the WTO for almost two years, putting the institution in an impasse. Behind the staggering blockage movement, nevertheless, import deficits, poor intellectual property rights protection, heavy involvement of the state-owned companies, and the unequal tariffs are the main factors that catalyzed the dissolution of the WTO.

Given the previous problems about the WTO, both internal and external, it is exceptionally challenging to reform such a complex institution that heavily relied on customary practices and preferential agreements in the era of China and U.S. leadership.[31] Inevitably, however, the WTO needs to reform and innovate in order to function better in what's left of this era. The reformation steps should be modest and progressive to avoid any commercial friction. In this scenario, improving the current structure of the institution by adjusting the evaluation and identification of the state members should be the priority. Moreover, officers need to submit updates for filed cases within the 90-day period. Helping different groups achieve profit is also critical for fixing the WTO since the it is conflicts between different groups that resulted in organized alliances such as the African Group and the Least-Developed Countries Group. Additionally, connecting with domestic WTO-like organizations ensures the sole authority of the state government on political choices in trading and the surrounding national joint layout development.

In addition to its institutional problems, the WTO should concentrate on repairing the bilateral relationship between China and the U.S. After witnessing the blistering economic boom and scientific breakthroughs of the 21st century, the world's economic status is closely related with the importation and tariff between the U.S. and Chinese economies. After the invention of PayPal, Alipay, and other digital payment applications, the banking system went through an escalating transformation that required global institutions to pay new attention. This brought a new collaborative opportunity to rebuild an amicable relationship between China and the U.S. based on cross-border transactions and manufacture. The WTO should seize the chance and 
form a set of new rules in the realm of e-commerce and digital trade policies to regain the respect from states by creating more values for multilateral cooperation.

\section{CONCLUSION}

In UNSC, WTO, and $\mathrm{HRC}$ cases, we can see the international institutions struggling in complex or even rivaling relationships between countries that may have amplified its structural deficiencies. Indeed, the proposals of structural changes among those institutions can be promoted for its accessibility, it may be hindered in enforcement for the lack of a consummate enforcer that would not be affected by any current supreme power. A sheer structural change might only modify the major powers 'arena with additional rules, but things might be different if the institutional reform is paired with sincere communications and corporations between not only major powers like China and the U.S but also other countries around the world. However, with the everlasting distrust among countries and the increasing rivalry between the major powers recently, we might only expect such multipartite understanding in a future of uncertainty. Through hundreds of professionals who have made their blueprint of the reforms in UNSC, HRC, or WTO, the reform's success is still decided by whether the countries can stop exploiting those institutions for their profit, with wholehearted cooperation facing global challenges. Especially in this uncertain time, we are expecting reforming rather than exploiting; communication rather than censure; and consociation rather than enmity.

\section{REFERENCES}

[1] History of the UN seventieth anniversary, United Nations. [Online]. Available: https://www.un.org/un70/en/content/history/index. html. [Accessed: 20-Oct-2021]

[2] Bederman, D.J. and Robbins, K.C.I. (2016) International Organizations. In International law frameworks Foundation Press

[3] 24-Jun-(2018), Xi urges breaking new ground in major country diplomacy with Chinese characteristics, Xinhua. [Online]. Available: http://www.xinhuanet.com/english/2018-06/24/c_1 37276269.htm. [Accessed: 14-Oct-2021]

[4] Adam Lupel and Lauri Malksoo. (2019) Obstacles and Opportunities for Small States on the Security Council. International Peace Institute, 1

[5] United Nations, Security Council, United Nations. [Online]. Available: https://research.un.org/en/docs/sc/quick. [Accessed: 20-Oct-2021]

[6] United Nations Security Council 7825th meeting.
United Nations. [Online]. Available: https://undocs.org/en/S/PV.7825. [Accessed: 20-Oct-2021]

[7] Andrea Royeppen. (2016) UNITED NATIONS SECURITY COUNCIL REFORM. Institute for Global Dialogue, 7.

[8] Hatuel-Radoshitzky, M. Criticism of the UN Security Council Veto Mechanism: Ramifications for Israel. Inss.org.il. [Online]. Available: https://www.inss.org.il/publication/criticism-of-theun-security-council-veto-mechanism-ramificationsfor-israel/. [Accessed: 20-Oct-2021]

[9] Murthy, C.S.R. (2007) New phase in UN reforms. International Studies 44, 45.

[10] Freedman, R. and Houghton, R. (2017) Two steps forward, one step back: Politicisation of the human rights council. Human Rights Law Review 17, 753-769.

[11] SCHRIJVER, N.I.C.O. (2007) The UN Human Rights Council: A new 'society of the committed' or just old wine in new bottles? Leiden Journal of International Law 20, 809-823.

[12] Freedman, R. and Houghton, R. (2017) Two steps forward, one step back: Politicisation of the human rights council. Human Rights Law Review 17, 753-769.

[13] Rosa Freedman. (2013) The United Nations Human Rights Council: More of the Same? Wisconsin Journal of International Law, 209-251.

[14] Freedman, R. and Houghton, R. (2017) Two steps forward, one step back: Politicisation of the human rights council. Human Rights Law Review 17, 753-769.

[15] Ibid.

[16] 23-Mar-(2021) , Joint statement on Xinjiang United States Department of State, U.S. Department of State. [Online]. Available: https://www.state.gov/joint-statement-on-xinjiang/. [Accessed: 14-Oct-2021]

[17] 17-Oct-(2018), United States withdraws from the UN Human Rights Council, shortly after receiving criticism about its border policy: American Journal of International law. Cambridge Core. [Online]. Available:

https://www.cambridge.org/core/journals/americanjournal-of-international-law/article/united-states-wi thdraws-from-the-un-human-rights-council-shortlyafter-receiving-criticism-about-its-border-policy/62 D716ED36F699ADD255D98940A14F99.

[Accessed: 14-Oct-2021] 
[18] 08-Jul-(2021), Secretary Blinken's roundtable with Xinjiang Internment Camp\&nbsp;survivors and advocates - united states department of state, U.S. Department of State. [Online]. Available: https://www.state.gov/secretary-blinkens-roundtabl e-with-xinjiang-internment-camp-survivors-and-ad vocates/. [Accessed: 14-Oct-2021]

[19] 04-May-(2001) , Opinion, 'Vote for Justice, Embarrassment for US.', People's Daily (China)

[20] Murthy, C.S.R. (2007) New phase in UN reforms. International Studies 44, 49.

[21] Walling, C.B. (2015) Human rights norms, State Sovereignty, and humanitarian intervention. Human Rights Quarterly 37, 383-413.

[22] Drishti IAS 17-Dec-(2020), Challenges Faced By The WTO. Drishti IAS. [Online]. Available: https://www.drishtiias.com/daily-updates/daily-new s-editorials/challenges-faced-by-the-wto.

[Accessed: 20-Oct-2021]

[23] Ibid.

[24] Barnett, M. Power in global governance. Cambridge Core. [Online]. Available: https://www.cambridge.org/core/books/power-in-gl obal-governance/ADFB5D161CF5A72F3A7DD72 AB9338677. [Accessed: 20-Oct-2021]

[25] Robert O. Keohane And Joseph S. Nye Jr. 02-Sep-(2003) , The club model of multilateral cooperation and Problems of Democratic. Taylor \&amp; Francis. [Online]. Available: https://www.taylorfrancis.com/chapters/edit/10.432 4/9780203218174-18/club-model-multilateral-coop eration-problems-democratic-legitimacy-2001-robe rt-keohane-joseph-nye-jr. [Accessed: 20-Oct-2021]

[26] Cooper, R.N. and Porter, R.B. (2002) Efficiency, equity, legitimacy: The Multilateral Trading System at the millennium. Foreign Affairs 81

[27] Jackson, J.H. World Trade and the law of GATT. [Online].

Available: https://www.jstor.org/stable/1121282. [Accessed: 20-Oct-2021]

[28] Jackson, J. (2018) Reflections on constitutional changes to the Global Trading System. International Economic Regulation. DOI: 10.4324/9781315183930-5

[29] Messerlin, P.A. (2005) Three variations on 'The future of the wto.' Journal of International Economic Law 8, 299-309

[30] Franck, T.M. (1992) The power of legitimacy among nations. Verfassung in Recht und Übersee $25,256-258$
[31] An economic analysis of the US-china trade conflict. [Online]. Available: https://www.wto.org/english/res_e/reser_e/ersd 202 004_e.pdf. [Accessed: 20-Oct-2021] 